\title{
Late Palaeolithic and Mesolithic Treatment and Use of Non-flint Stone Raw Materials: Material Collection From Site 17 at Nowogród, Golub-Dobrzyń District, Poland
}

\author{
Grzegorz Osipowicz ${ }^{a}$, Piotr Chachlikowski ${ }^{b}$, Justyna Orłowskac, \\ Zsolt Kasztovszky ${ }^{\mathrm{d}}$, Rafał Siuda ${ }^{\mathrm{e}}$ and Piotr Weckwerth ${ }^{\mathrm{f}}$
}

\begin{abstract}
The aim of the article is to present the results of a multifaceted analysis of a collection of non-flint stone artefacts obtained during excavations of the complex of Late Palaeolithic camps at site 17 in Nowogród, Golub-Dobrzyń district. It included an obsidian artefact and objects made of crystalline rocks (quartzite, quartzite sandstone, quartz, coarse sandstone and diorite), which were created as a result of knapping the raw material using techniques similar or identical to those used during the processing of flint. The results of petrographic analysis confirmed that these raw materials had come from natural resources located near the site. Most of the analysed artefacts are represented by large flakes. In addition, one chip and two tools, a multiple burin and a pebble tool, were distinguished. Use-wear analysis showed signs of use on two artefacts, including the pebble tool. The obsidian artefact is currently the northernmost Late Palaeolithic find of this type. In order to determine the geological source of the raw material, the artefact was subjected to PGAA and XRF analysis. PGAA analysis confirmed that the obsidian originated from a source in northern Slovakia (Carpathian I type), probably from the Cejkov or Kašov deposits, Trebišov district. The article also describes a rock crystal and a probable concretion of quartz of this type originating from site 6 in Ludowice, Wąbrzeźno district.
\end{abstract}

KEY-WORDS: Late Palaeolithic, stone, non-flint raw materials, obsidian, traceology, PGAA, XRF, Polish Lowlands

${ }^{a}$ Institute of Archaeology, Nicolaus Copernicus University, ul. Szosa Bydgoska 44/48, 87-Ioo Toruń, Poland; e-mail: grezegor@umk.pl; ORCID: 000o-0002-4393-655X

b Institute of Archaeology, Adam Mickiewicz University, Collegium Historicum, ul. Umultowska 89D, 6I-6I4 Poznań; piocha@amu.edu.pl; ORCID: 00oo-0002-2138-2250

c Institute of Archaeology, Nicolaus Copernicus University, ul. Szosa Bydgoska 44/48, 87-Ioo Toruń, Poland; e-mail: e-mail: orlowskajustyna@wp.pl; ORCID: oooo-ooo2-7843-3506

d Centre for Energy Research Hungarian Academy of Sciences H-I525 Budapest P.O. Box 49 Hungary; e-mail: kasztovszky.zsolt@energia.mta.hu; ORCID: 0000-0002-5745-8616

e Faculty of Geology, University of Warsaw, ul. Żwirki i Wigury 93, 02-089 Warszawa, Poland; e-mail: rsiuda@uw.edu.pl; ORCID: 0000-0003-4I53-8539

${ }^{f}$ Faculty of Earth Sciences, Nicolaus Copernicus University, ul. Lwowska I, 87-Ioo Toruń, Poland; e-mail: pweck@umk.pl; ORCID: 00oo-0002-2617-2383 
IO4 Osipowicz et al

The present day territory of Poland was, in the Stone Age, a 'privileged' region owing to the numerous outcrops of high-quality, flint raw materials. Thus, for the communities of this period, flint was the basic raw material processed using knapping techniques and used for the production of stone tools. Nevertheless, for various reasons, prehistoric people did not completely abandon the use of other types of rocks. Unfortunately, this is sometimes downplayed by researchers specializing in this period, despite the appearance of publications on new collections of prehistoric stone artefacts made from non-flint rocks that are being discovered in Poland. Changing this state of affairs is imperative, only by taking into account all types of raw materials found on prehistoric sites, and analyzing them in a multifaceted way, will we be able to create a more objective vision of the economy and other aspects of life of prehistoric communities.

The main goal of this article is the presentation and multifaceted analysis of a collection of stone products made from non-flint raw materials that were obtained during excavations of the complex of Late Palaeolithic camps at site 17 in Nowogród, Golub-Dobrzyń district. It included objects made of crystalline rocks that were created as a result of knapping the raw material using techniques similar or identical to those used during the processing of flint. There is also an obsidian artefact from this site, which we believe is the northernmost Late Palaeolithic find of this type.

The article also discusses a previously undescribed fragment of rock crystal and a probable concretion of quartz of this type found at site 6 in Ludowice, Wąbrzeźno district, that had been omitted from previous publications about the site. The reason for their inclusion is the individuality and uniqueness of these findings in the context of other hunter-gatherer sites in the Polish Lowlands.

\section{MATERIALS AND METHODS}

Site I7 in Nowogród is located on a promontory in the subglacial valley of Grodno and Plebanka lakes, in the northern part of the Chełmno-Dobrzyń Lake District. It is one of several sites there (Fig. I), currently excavated under the project titled: Mesolithic communities of the Chetmno-Dobrzyn Lakeland - daily life, mobility, external contacts and relationships with the environment, which is funded by the National Science Center (NCN) in Cracow (Poland; project no. 2016/23/B/HS3/o0689). Archaeological research, covering an area of $232 \mathrm{~m}^{2}$, took place here from 20I4-20I5. Abundant remains of prehistoric settlements were found on the site, mainly associated with groups of Late Palaeolithic and Mesolithic hunter-gatherers. The artefacts recovered are currently undergoing multifaceted analyses, the results of which will be published in the near future. This article concerns the collection of non-flint stone products from the site, totalling 17 specimens (including the obsidian artefact). 


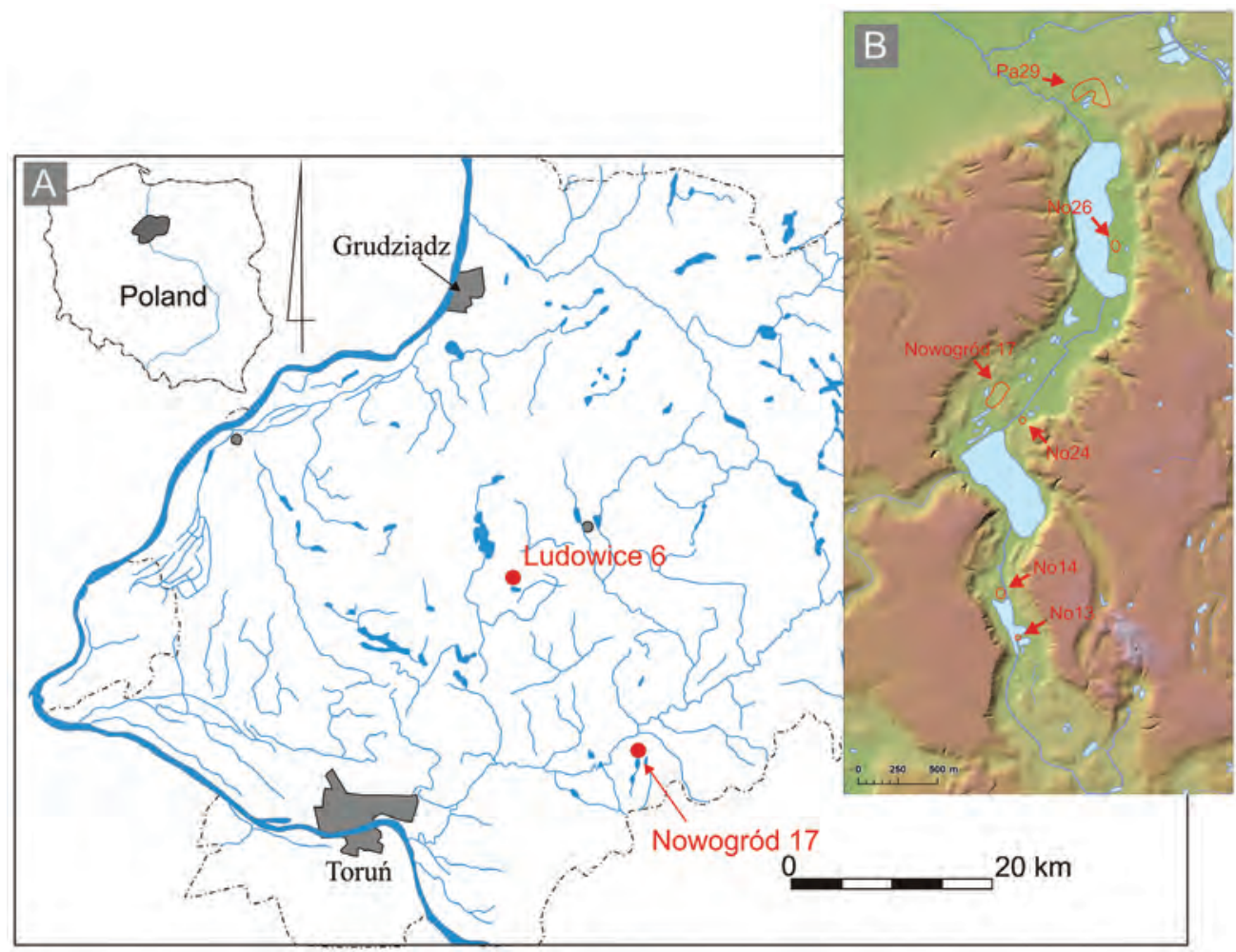

Fig. 1. Location of the archaeological sites included: A - location within the Chełmno-Dobrzyń Lake District; B - location of the site 17 in Nowogród, Golub-Dobrzyń district, within the subglacial valley of the lakes Grodno and Plebanka, with the location of other Late Palaeleolitic and Mesolithic sites.

Drawn: G. Osipowicz.

Ludowice 6 site is located in the central part of the Chełmno Lake District, on the Chełmińska Height (central Poland), in the contact zone of an outwash plain (or sandur) and a large kettle hole, filled with biogenic sediments (peat). Archaeological research, covering an area of $756 \mathrm{~m}^{2}$, took place here from 2009-20I4 (Osipowicz et al., 20I4). On the site, remains of Late Glacial (Swiderian culture) and early Holocene (Mesolithic) settlements were found. The main settlement phase took place in the Late Mesolithic, when the site was frequently visited by people of the late Komornica culture (post-Maglemose tradition). The settlement remains from this period are a complex of short-term, seasonal camps specializing in the processing of silica-rich plants (Osipowicz 20I7a, b). Archaeological research conducted within the site provided a rich and diverse collection of prehistoric artefacts, among which was a group of Mesolithic stone products made mainly of red quartz porphyry, ferruginous quartz sandstone or fine-grained red granite. They form a unique stone industry that has been described in previous publica- 
Io6 $\mid$ Osipowicz et al

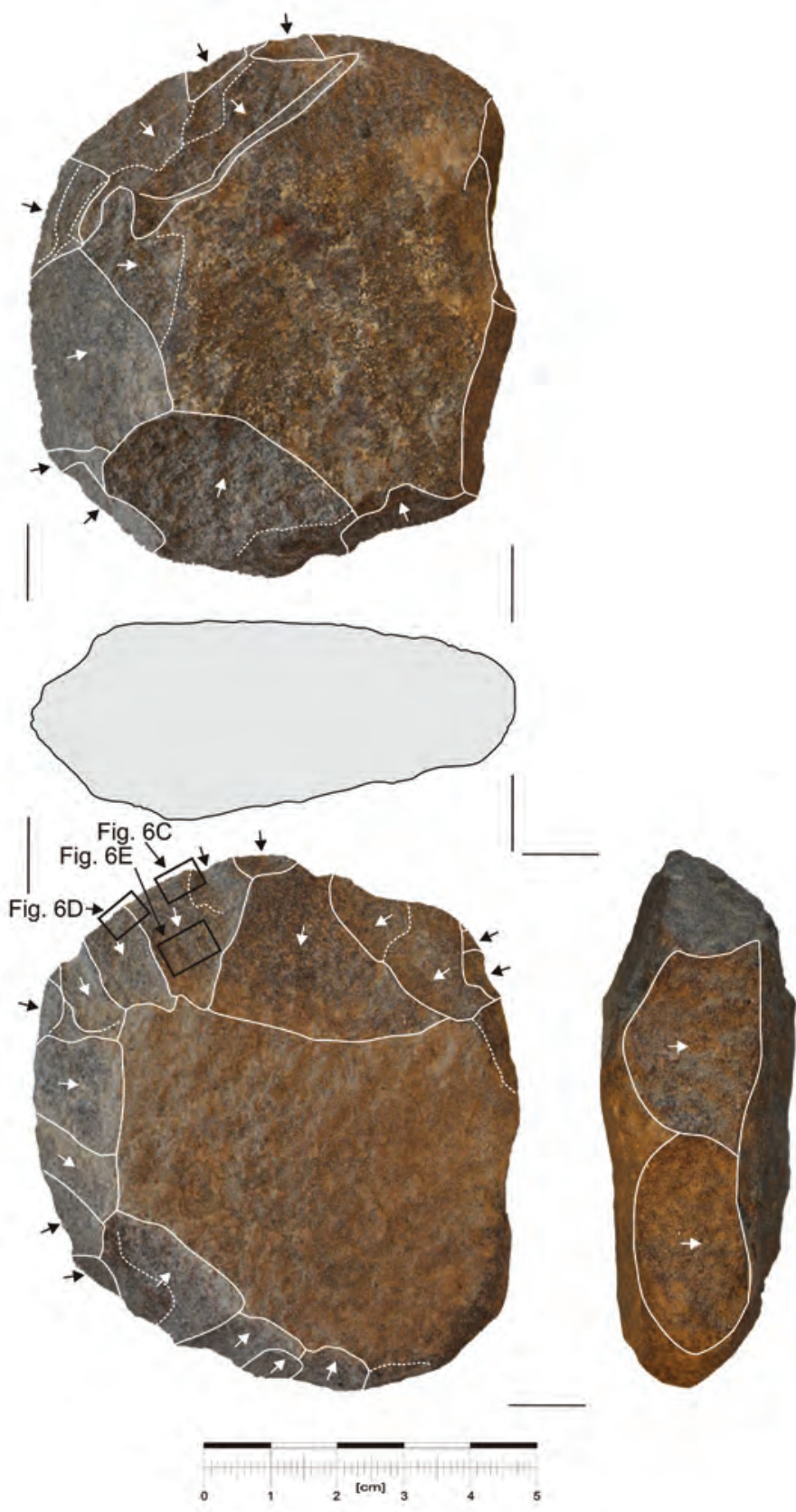

Fig. 2. Nowogród, site. 17, Golub-Dobrzyń district. Pebble tool. Computer graphics: G. Osipowicz and J. Orłowska. 

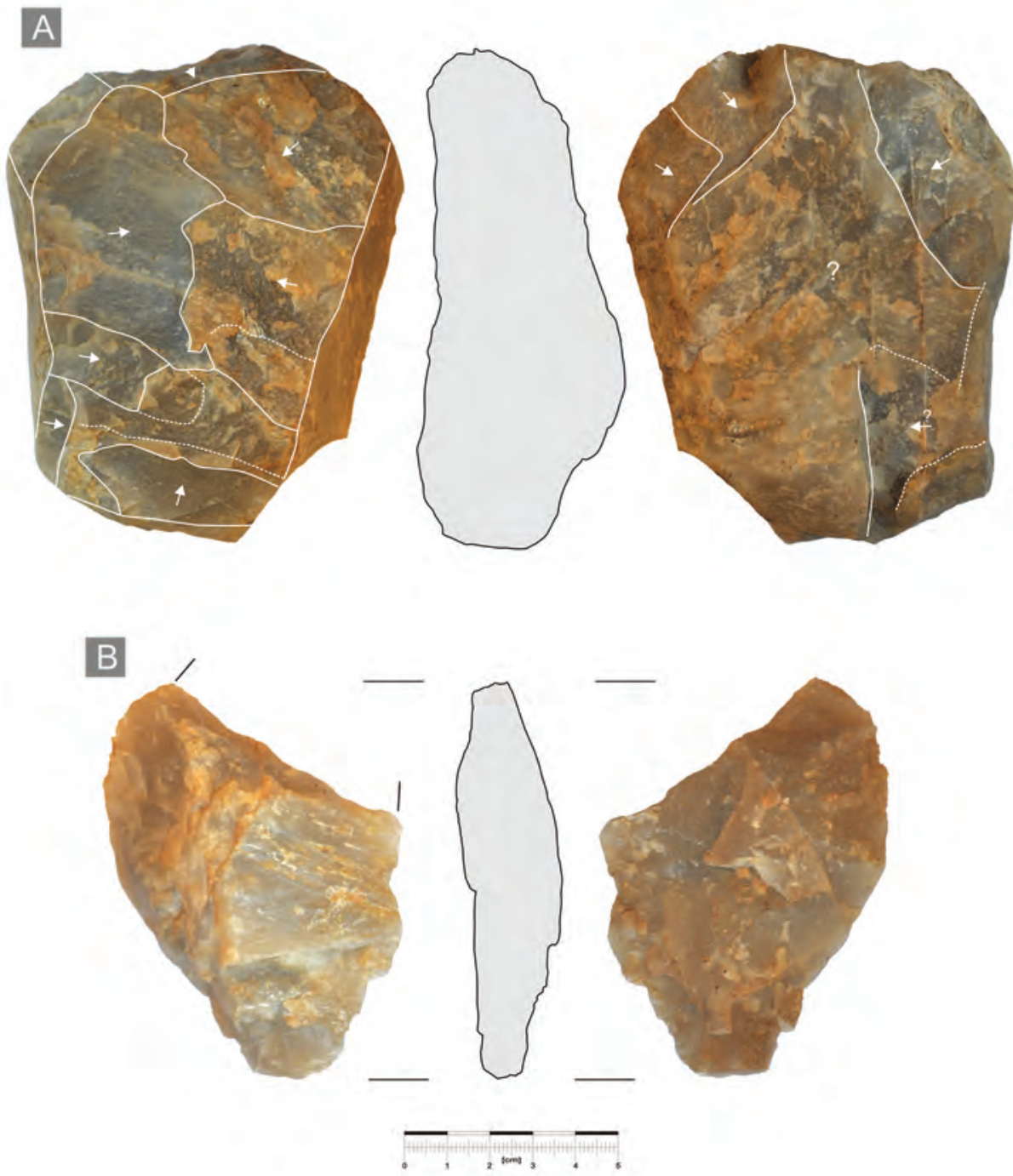

Fig. 3. Nowogród, site. 17, Golub-Dobrzyń district. Selection of stone artifact. Computer graphics: G. Osipowicz and J. Orłowska. 
IO8 Osipowicz et al
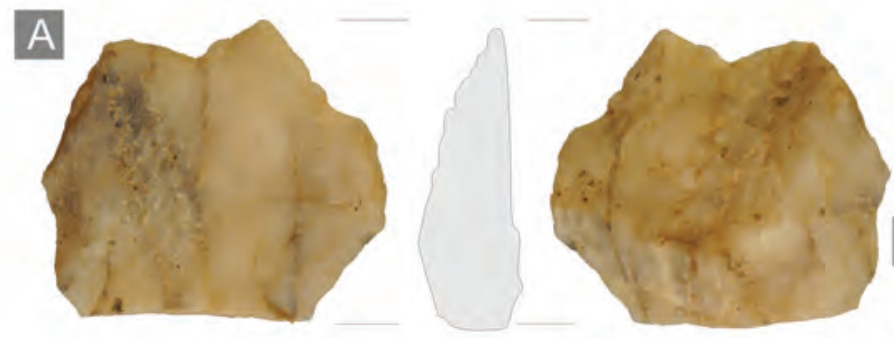

\section{B}
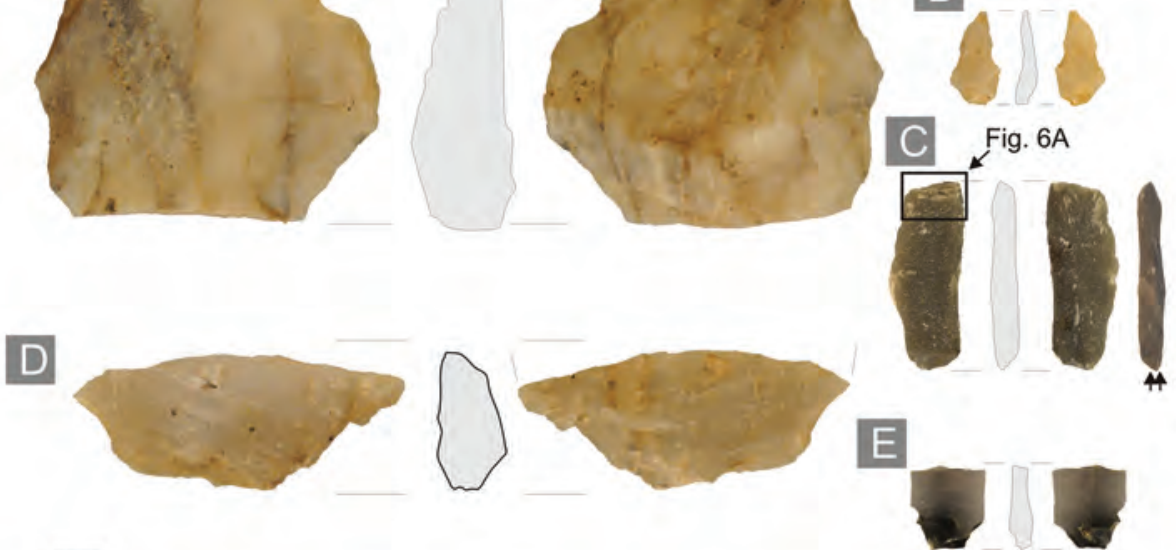

$\mathrm{F}$
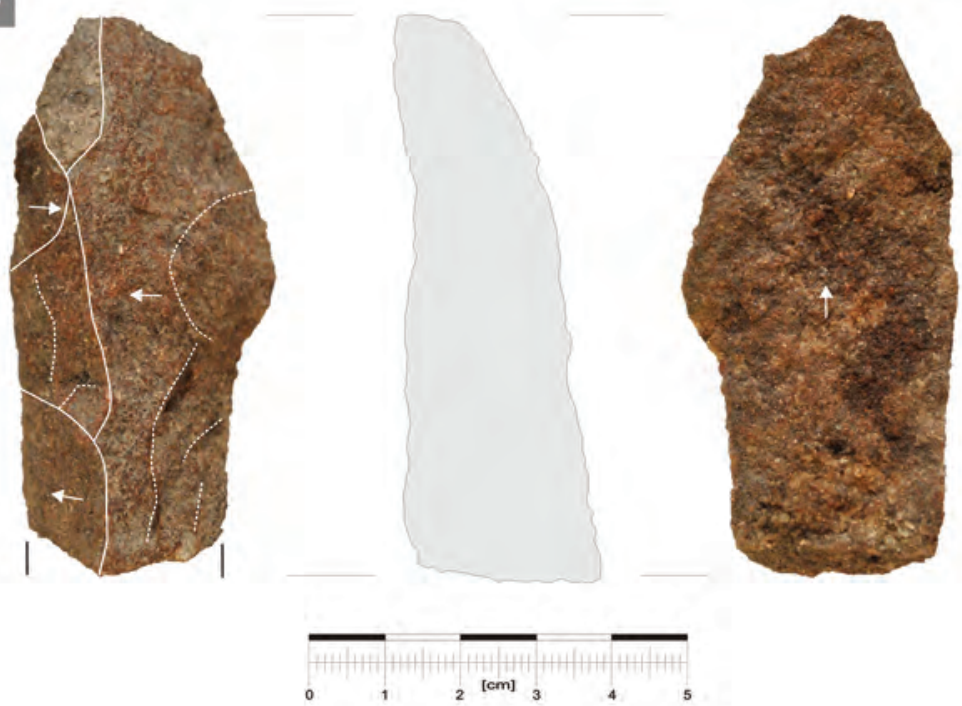

Fig. 4. Nowogród, site. 17, Golub-Dobrzyń district. Selection of stone artifact. Computer graphics: G. Osipowicz and J. Orłowska. 
tions (Osipowicz and Sobkowiak-Tabaka 20I4; Osipowicz 20I5). Other non-flint stone artefacts were also found on the site, comprising mainly macrolithic tools. The rock crystal piece included in the study and the probable concretion of quartz of this type originated from the humus layer over one of the Mesolithic habitation areas, however their relation to the Late Glacial communities, whose camps was discovered only a few metres away, cannot be excluded. Unfortunately, the probable concretion of rock crystal was lost in unclear circumstances during the preparation of this study, therefore, it was impossible to include photographs or drawings, as well as photomicrographs of post-depositional damages observed on it. All artefacts were subjected to technological, typological, petrographic and use-wear analysis. In order to identify the geological source of the obsidian found at Nowogród, it was subjected to Prompt Gamma-Ray Activation Analysis (PGAA) and X-ray Fluorescence Analysis (XRF). The petrographic characteristics of stone materials of all the artefacts were assessed by macroscopic methods (naked eye and under the magnifying glass). The lithological examinations were applied only to materials that appeared to have been worked.

Traceological analyses were performed using two microscopes. The initial examination was done using a Nikon SMZ-2T microscope with up to I2.6X magnification (virtual magnification up to I20X) fitted with a Nikon D7Ioo digital SLR camera body. The photomicrographs presented in Fig. 6A-E were also made with this equipment. Observations of polish were done using a Zeiss-Axiotech microscope with up to $50 \mathrm{X}$ magnification (virtual magnification up to 500X) fitted with an Axiocam ios camera. The photomicrograph presented in Fig. $6 \mathrm{~F}$ was also made with this equipment. The terminology and methodology of the use-wear analysis performed for this paper have been described in previous publications (see Osipowicz 2010 and references therein). Microscopic investigations of the stone artefacts described in this paper were extremely difficult due to the coarse crystallinity of the raw material used during the production of most of the artefacts, and the lack of an appropriate comparative database for the recorded damage in the form of a collection of experimental artefacts. For this reason, only a very general description of the traces observed, and a cautious interpretation of their genesis, was made.

PGAA was carried out at the Prompt Gamma Activation Analysis facility of the Budapest Neutron Centre (BNC), operated by the Centre for Energy Research, Hungarian Academy of Sciences. The obsidian piece was placed into the horizontal cold neutron beam and irradiated for $18000 \mathrm{~s}(5 \mathrm{~h})$. The neutron flux at the sample position of the PGAA station was about $9.6 \times 10^{7} \mathrm{~cm}^{-2} \mathrm{~s}^{-1}$. The cross-section of the neutron beam was adjusted to $4 \mathrm{~cm}^{2}$, so as to ensure the whole object is illuminated by the neutrons. The gamma radiation from the radiative neutron capture was detected with a HighPurity Germanium (HPGe) detector, surrounded by a Bismuth Germanate (BGO) scintillator and lead shielding; the signals were processed with a Canberra AIM 556A multichannel analyser. The facility has been described in detail in an earlier publication 
IIO $\mid$ Osipowicz et al
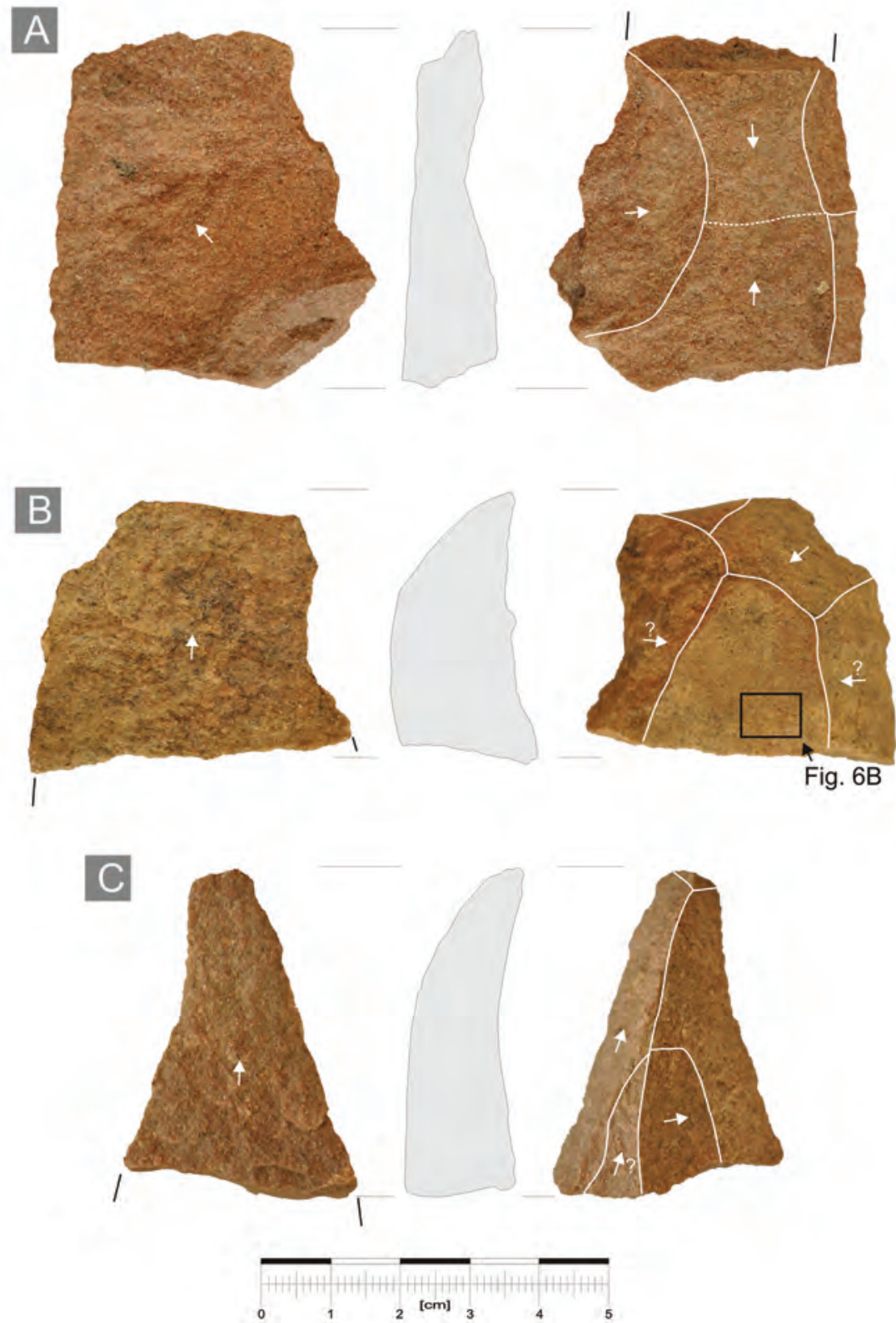

Fig. 5. Nowogród, site. 17, Golub-Dobrzyń district. Selection of stone artifact. Computer graphics: G. Osipowicz and J. Orłowska. 
Late Palaeolithic and Mesolithic Treatment and Use of Non-flint Stone Raw Materials III
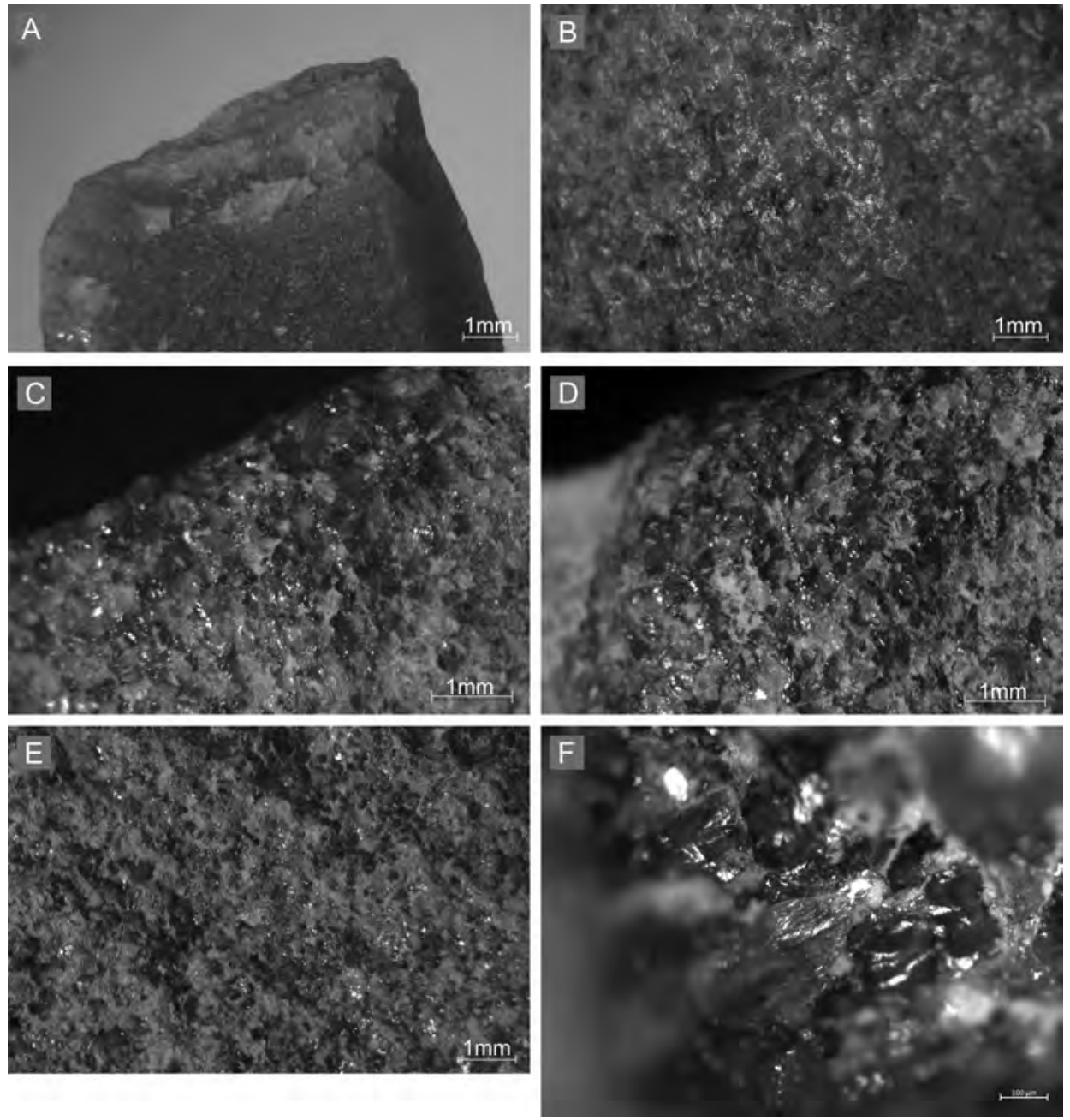

Fig. 6. Nowogród, site. 17, Golub-Dobrzyń district. Usage and technological traces observed on stone artefacts. Photo: G. Osipowicz. 
II2 $\mid$ Osipowicz et al

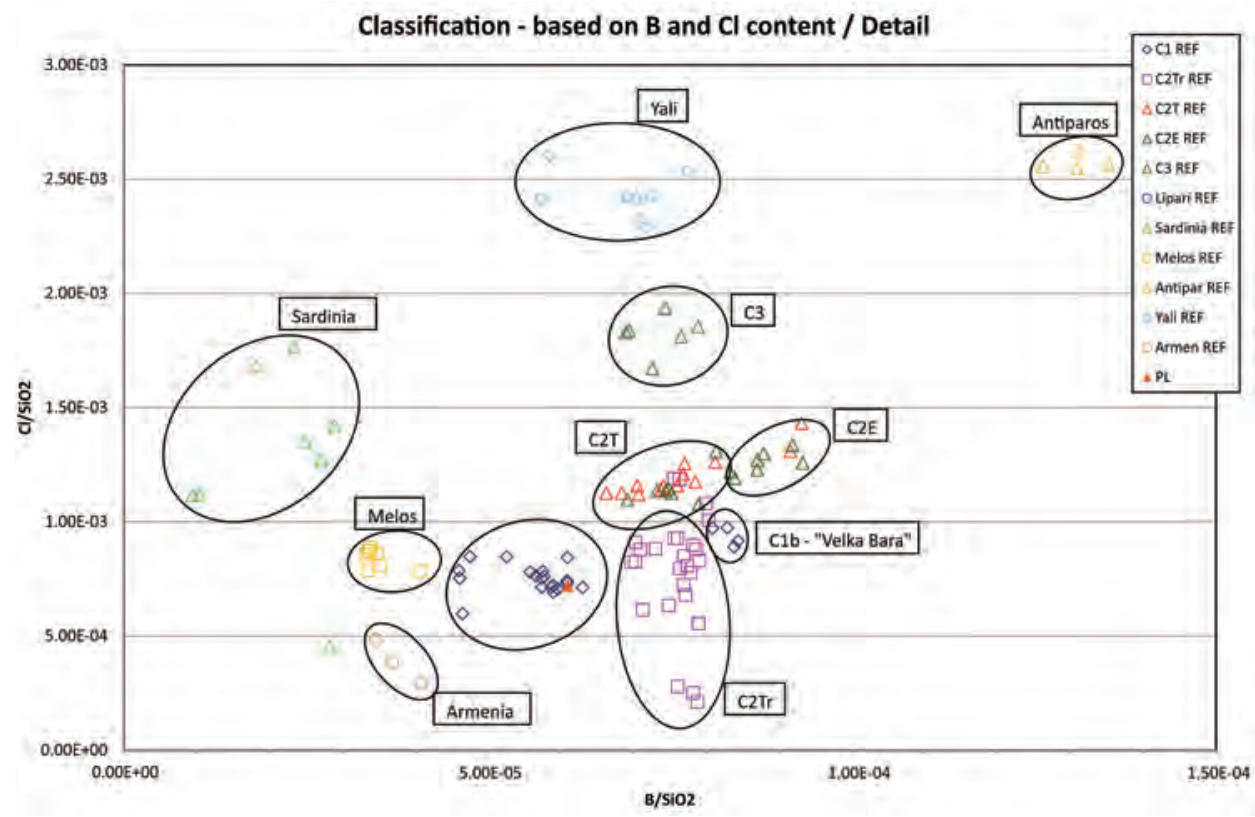

Fig. 7. The results of PGAA: classification based on $\mathrm{B}$ and $\mathrm{Cl}$ content. Computer graphics:

Z. Kasztovszky.

(Szentmiklósi et al., 20I0). The spectrum was evaluated with Hypermet-PC gamma spectroscopy software. The element identification was done with the program ProSpeRo (Révay 2009), utilizing Prompt-Gamma Analysis Library (Révay et al., 2004). The beam background has been adequately corrected for.

$\mathrm{XRF}$ analysis was performed using an X-ray spectrometer PANalytical MinPan4 (PW4025/oo type) using X-ray fluorescence. The obsidian sample was placed in a Teflon test cuvette with a bottom made of a Kapton foil. The measurement was carried out at a voltage of $\mathrm{I} 4 \mathrm{kV}$ and an amperage of $150 \mu \mathrm{A}$. Four measurements were carried out (two for each side of the artefact). The measurement time was 60 or 120 seconds. The device has been calibrated based on geological reference materials (molten granite and basalt).

\section{RESULTS}

Petrographic, typological and technological analyses

Detailed raw material and typological characteristics are presented in Table I. Selected artefacts are presented in Fig. 2-5. The Late Palaeolithic population living at site I7 


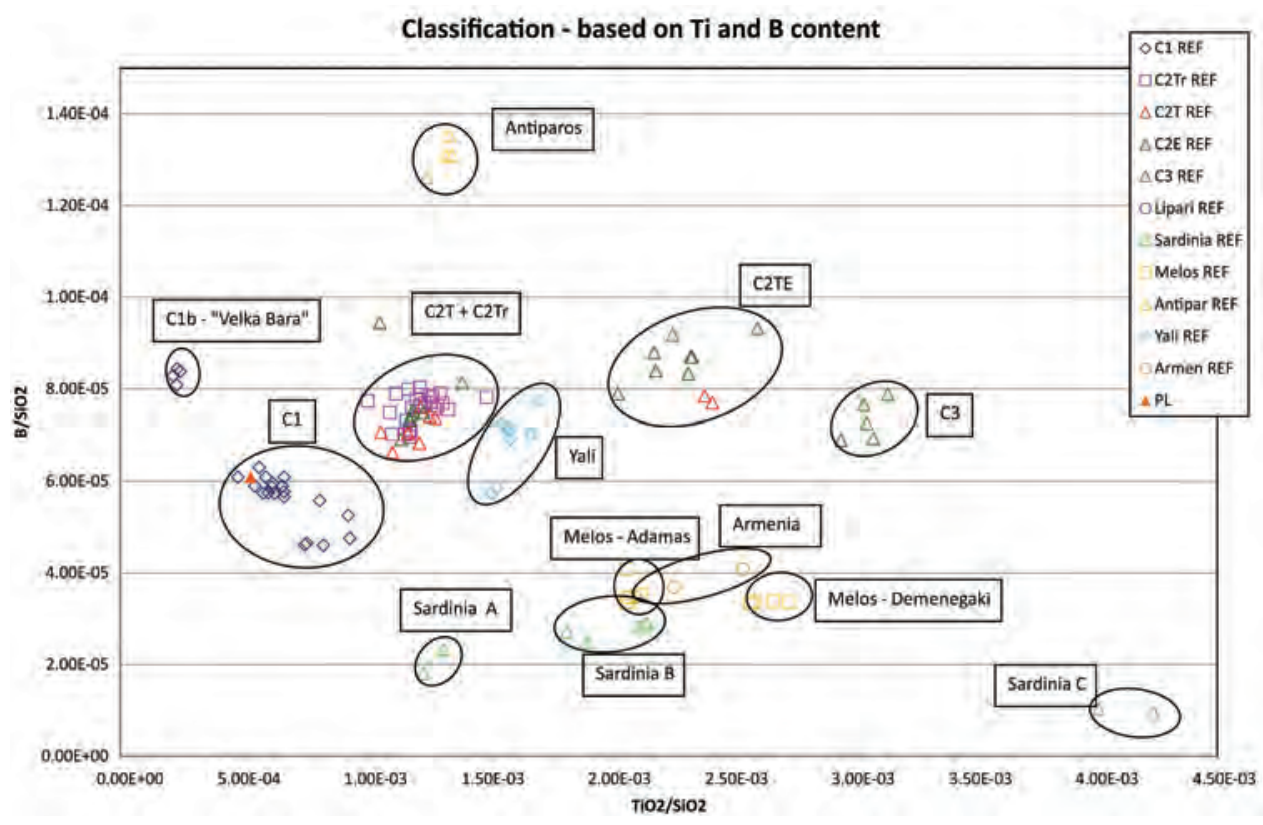

Fig. 8. The results of PGAA: classification based on Ti and B content. Computer graphics:

Z. Kasztovszky.

in Nowogród used a rather diversified, but carefully selected, range of raw materials in stone processing. Among the stone materials used, four lithological varieties of rocks were distinguished. The most commonly used were quartzite (eight of the 17 finds) and quartzite sandstone ( 5 specimens). Other other rock types were used less frequently, represented by single specimens of quartz, coarse sandstone and diorite. The rock crystal concretion found on the site at Ludowice and the second concretion are heavily affected by postdepositional processes, which caused problems with the precise determination of the lithology of the second specimen.

Most of the artefacts analyzed (II specimens) are large flakes. A chip and two tools were also identified. Of the tools one is the single blow multiple burin made (probably) on a quartzite blade (Fig. $4 \mathrm{C}$ ). The second is more interesting, because it is (probably) a diorite pebble, processed on both sides around the circumference so as to create a semicircular blade covering about three-quarters of the edge on the artefact (Fig. 2). The artefact also has a kind of back formed by (blunting) negatives of flakes that are perpendicular to its axis. The object can be considered as a type of two-sided pebble tool although, considering its morphological characteristics, it cannot be ruled out that it is a kind of pre-core form of a double platform core in which preparation of the 
Table. 1. Results of raw material, morphological and traceological analysis of the described stone artefacts.

\begin{tabular}{|c|c|c|c|c|c|c|}
\hline No. & Site Name & $\begin{array}{c}\text { Inwentory } \\
\text { number }\end{array}$ & $\begin{array}{c}\text { Raw } \\
\text { material }\end{array}$ & $\begin{array}{c}\text { Morphological } \\
\text { description }\end{array}$ & $\begin{array}{l}\text { Traceological } \\
\text { description }\end{array}$ & Figure \\
\hline 1. & $\begin{array}{l}\text { Nowogród, } \\
\text { site } 17\end{array}$ & 728 & quartzite & $\begin{array}{l}\text { fragment of a large } \\
\text { flake }\end{array}$ & $\begin{array}{l}\text { flake removed from } \\
\text { grinding plate or } \\
\text { grinding stone }\end{array}$ & $\begin{array}{l}\text { Fig. 5B, } \\
6 B\end{array}$ \\
\hline 2. & \begin{tabular}{|l|} 
Nowogród, \\
site 17
\end{tabular} & 730 & \begin{tabular}{|l} 
coarse \\
sandstone
\end{tabular} & flake & no sign of use & \\
\hline 3. & $\begin{array}{l}\text { Nowogród, } \\
\text { site } 17\end{array}$ & 732 & $\begin{array}{l}\text { fine-grained } \\
\text { quartzite } \\
\text { sandstone }\end{array}$ & flake & no sign of use & \\
\hline 4. & $\begin{array}{l}\text { Nowogród, } \\
\text { site } 17\end{array}$ & 751 & quartzite & fragment of a flake & no sign of use & Fig. 4D \\
\hline 5. & $\begin{array}{l}\text { Nowogród, } \\
\text { site } 17\end{array}$ & 738 & $\begin{array}{l}\text { quartzite } \\
\text { sandstone }\end{array}$ & flake & no sign of use & Fig. $5 \mathrm{~A}$ \\
\hline 6. & \begin{tabular}{|l|} 
Nowogród, \\
site 17
\end{tabular} & 748 & quartzite & flake & no sign of use & Fig. 4A \\
\hline 7. & \begin{tabular}{|l|} 
Nowogród, \\
site 17
\end{tabular} & 749 & $\begin{array}{l}\text { quartzite } \\
\text { sandstone }\end{array}$ & fragment of a flake & no sign of use & Fig. 5C \\
\hline 8. & $\begin{array}{l}\text { Nowogród, } \\
\text { site } 17\end{array}$ & 752 & $\begin{array}{l}\text { quartzite } \\
\text { sandstone }\end{array}$ & flake & no sign of use & Fig. 4F \\
\hline 9. & $\begin{array}{l}\text { Nowogród, } \\
\text { site } 17\end{array}$ & 753 & quartzite & flake & no sign of use & Fig. 3B \\
\hline 10. & $\begin{array}{l}\text { Nowogród, } \\
\text { site } 17\end{array}$ & 754 & quartzite & $\begin{array}{l}\text { single blow multiple } \\
\text { burin made (prob- } \\
\text { ably) on blade }\end{array}$ & $\begin{array}{l}\text { well-readable tech- } \\
\text { nological traces (hard } \\
\text { hammer technique) }\end{array}$ & $\begin{array}{l}\text { Fig. } 4 \mathrm{C}, \\
6 \mathrm{~A}\end{array}$ \\
\hline 11. & \begin{tabular}{|l|} 
Nowogród, \\
site 17
\end{tabular} & 757 & \begin{tabular}{|l} 
quartzite \\
sandstone
\end{tabular} & flake & no sign of use & \\
\hline 12. & $\begin{array}{l}\text { Nowogród, } \\
\text { site } 17\end{array}$ & 759 & quartzite & fragment of a flake & no sign of use & \\
\hline 13. & $\begin{array}{l}\text { Nowogród, } \\
\text { site } 17\end{array}$ & 764 & quartz & flake & no sign of use & \\
\hline 14. & $\begin{array}{l}\text { Nowogród, } \\
\text { site } 17\end{array}$ & 765 & diorite (?) & pebble tool & $\begin{array}{l}\text { probably used, activ- } \\
\text { ity unspecified }\end{array}$ & $\begin{array}{l}\text { Fig. } 2 \text {, } \\
\text { 6C-E }\end{array}$ \\
\hline 15. & $\begin{array}{l}\text { Nowogród, } \\
\text { site } 17\end{array}$ & 767 & quartzite & precore form & no sign of use & Fig. 3A \\
\hline 16. & $\begin{array}{l}\text { Nowogród, } \\
\text { site } 17\end{array}$ & 768 & quartzite & chip & no sign of use & Fig. 4B \\
\hline 17 & $\begin{array}{l}\text { Nowogród, } \\
\text { site } 17\end{array}$ & 758 & obsidian & butt part of blade & no sign of use & Fig. 4E \\
\hline 18 & $\begin{array}{l}\text { Ludowice, } \\
\text { site } 6\end{array}$ & 670 & $\begin{array}{l}\text { quartz / rock } \\
\text { crystal (?) }\end{array}$ & concretion & no sign of use & \\
\hline 19 & $\begin{array}{l}\text { Ludowice, } \\
\text { site } 6\end{array}$ & 173 & rock crystal & concretion & no sign of use & \\
\hline
\end{tabular}


future flaking surface and both platforms had been made. All the artefacts described were made using hard hammer technique.

The obsidian artefact found at Nowogród is the proximal part of a small blade. Both suggested concretions of rock crystal found at the Ludowice site show no obvious traces of processing.

\section{Use-wear analysis}

Use-wear analysis of the stone artefacts from the site at Nowogród did not lead to the identification of damage that could be unambiguously considered as traces of use. Most of the pieces analysed show no signs of use at all. On some of them are only identifiable technological traces resulting from the use of a hard hammer, in the form of different types of crushing and exfoliation (Fig. 6A). On one of the surfaces on a fragment of a large quartzite flake (inventory number 728), there was clearly visible rounding and linear polishing, which is probably the result of using the specimen (initially, before knapping) as a grinding slab or grinding stone (Fig. 6B). Undoubtedly, the most interesting traces were observed on the suggested pebble tool (inv. no. 765). On its circumference, in the place of separating the flakes to form the blade, crushing is clearly visible. Their origin is ambiguous; they could be related to the process of manufacturing, its use, or both. Clear rounding and smoothing of the microrelief of the raw material were also observed on the blade of the specimen (Fig. 6C and D). It did not occur on other parts of the artefact (Fig. 6E). In the rounded areas, a kind of shiny, linear polish was evident (Fig. 6F). Further characterization and interpretation were impossible for reasons given in the Methods section, above. However, it is possible to tell with a high degree of probability that the damage described has a usage origin, which suggests we are dealing with a used tool.

Microscopic analysis of the obsidian blade from the site at Nowogród revealed no signs of use. Both pieces of rock crystals found at the site at Ludowice were also subjected to traceological analysis. They do not bear traces of processing or use; however, clear rounding of their edges was visible, resulting from long-term post-depositional processes. Therefore, from the results of the traceological research, it is not certain if we are dealing with objects brought to the site by Late Palaeolithic or Mesolithic people, or whether they were already there as a result of the movement of the ice sheet.

\section{Analysis of the obsidian artefact using PGAA and XRF}

The PGAA results are summarized in Table 2 . With PGAA, we were able to quantify most of the major components in the obsidian (i.e., $\mathrm{SiO}_{2}, \mathrm{TiO}_{2}, \mathrm{Al}_{2} \mathrm{O}_{3}, \mathrm{Fe}_{2} \mathrm{O}_{3 \mathrm{t}}, \mathrm{MnO}$, $\mathrm{CaO}, \mathrm{Na}_{2} \mathrm{O}, \mathrm{K}_{2} \mathrm{O}, \mathrm{H}_{2} \mathrm{O}$ ), as well as some trace elements (i.e., B, $\mathrm{Cl}^{3}, \mathrm{Nd}, \mathrm{Sm}, \mathrm{Gd}$ ).

${ }^{1}$ Concentrations of major components are given as oxide values, while trace element concentrations are reported in parts per million ( $\mathrm{ppm}$ ) or micrograms/gram (ug/g) - all measurements are in weight \%. 
Table 2. Summary of the PGAA results of obsidian from site 17 at Nowogród, Golub-Dobrzyń district. The measured concentrations with one-sigma errors.

\begin{tabular}{|l|c|c|}
\hline Trace components & Conc. / wt $\%$ & Abs. Unc. / +/- \\
\hline $\mathrm{SiO} 2$ & 76.3 & 0.4 \\
\hline $\mathrm{TiO} 2$ & 0.041 & 0.002 \\
\hline $\mathrm{Al} 2 \mathrm{O} 3$ & 13.1 & 0.3 \\
\hline $\mathrm{Fe} 2 \mathrm{O} 3$ & 0.91 & 0.03 \\
\hline $\mathrm{MnO}$ & 0.059 & 0.002 \\
\hline $\mathrm{CaO}$ & 0.72 & 0.04 \\
\hline $\mathrm{Na} 2 \mathrm{O}$ & 3.72 & 0.08 \\
\hline $\mathrm{K} 2 \mathrm{O}$ & 4.84 & 0.10 \\
\hline $\mathrm{H} 2 \mathrm{O}$ & 0.282 & 0.007 \\
\hline $\mathrm{Cl}$ & 0.055 & 0.001 \\
\hline $\mathrm{B}$ & 0.0047 & 0.0001 \\
\hline $\mathrm{Sm}$ & 0.00037 & 0.00001 \\
\hline $\mathrm{Gd}$ & 0.00047 & 0.00003 \\
\hline
\end{tabular}

The $\mathrm{MgO}$ content of the samples was found to be below the quantification limit ( -0.9 weight\%). In Table 2 , the absolute uncertainties of the concentration values are also given. The concentrations are average values for the irradiated volume.

Among the trace elements, PGAA is especially applicable to detect B and Cl. Based on previous research, the major and trace components in obsidian are characteristic

Table 3. Summary of the XRF results of chemical composition of obsidian from site 17 at Nowogród, Golub-Dobrzyń district.

\begin{tabular}{|l|c|c|c|c|c|}
\hline \multicolumn{1}{|c|}{$w \mathrm{wt} \%$} & $\begin{array}{c}\text { Time } \\
\text { of analysis } 60 \mathrm{~s}\end{array}$ & $\begin{array}{c}\text { Time } \\
\text { of analysis } 120 \mathrm{~s}\end{array}$ & $\begin{array}{c}\text { Time } \\
\text { of analysis } 60 \mathrm{~s}\end{array}$ & $\begin{array}{c}\text { Time } \\
\text { of analysis } 120 \mathrm{~s}\end{array}$ & $\begin{array}{c}\text { Average } \\
(\mathrm{n}=4)\end{array}$ \\
\hline $\mathrm{Al}_{2} \mathrm{O}_{3}$ & 8.80 & 8.80 & 8.60 & 8.70 & 8.73 \\
\hline $\mathrm{SiO}_{2}$ & 72.90 & 73.00 & 72.90 & 72.80 & 72.90 \\
\hline $\mathrm{K}_{2} \mathrm{O}$ & 11.10 & 11.00 & 11.20 & 11.30 & 11.15 \\
\hline $\mathrm{CaO}$ & 2.52 & 2.52 & 2.54 & 2.54 & 2.53 \\
\hline $\mathrm{TiO}_{2}$ & 0.22 & 0.22 & 0.23 & 0.23 & 0.23 \\
\hline $\mathrm{MnO}$ & 0.25 & 0.24 & 0.25 & 0.25 & 0.25 \\
\hline $\mathrm{Fe}_{2} \mathrm{O}_{3}$ & 4.23 & 4.20 & 4.29 & 4.32 & 4.26 \\
\hline $\mathrm{Total}^{*}$ & 100.02 & 99.98 & 100.01 & 100.14 & 100.04 \\
\hline
\end{tabular}

* total without content of $\mathrm{H}_{2} \mathrm{O}$ and $\mathrm{NaO}$. 
for their geological origin (provenance; Kasztovszky et al., 2008; Kasztovszky et al., 2018). Based on the $\mathrm{B}, \mathrm{Cl}$ and $\mathrm{TiO}_{2}$ content, comparisons of the composition in the investigated objects to those in previously measured reference samples, we can ascertain the provenance of the 'unknown' samples, with high reliability (Fig. 7 and 8).

As a conclusion, it can be said that the investigated sample (marked as 'PL') proved to be the Ci ('Carpathian I') type, most likely from the sources Cejkov or Kašov.

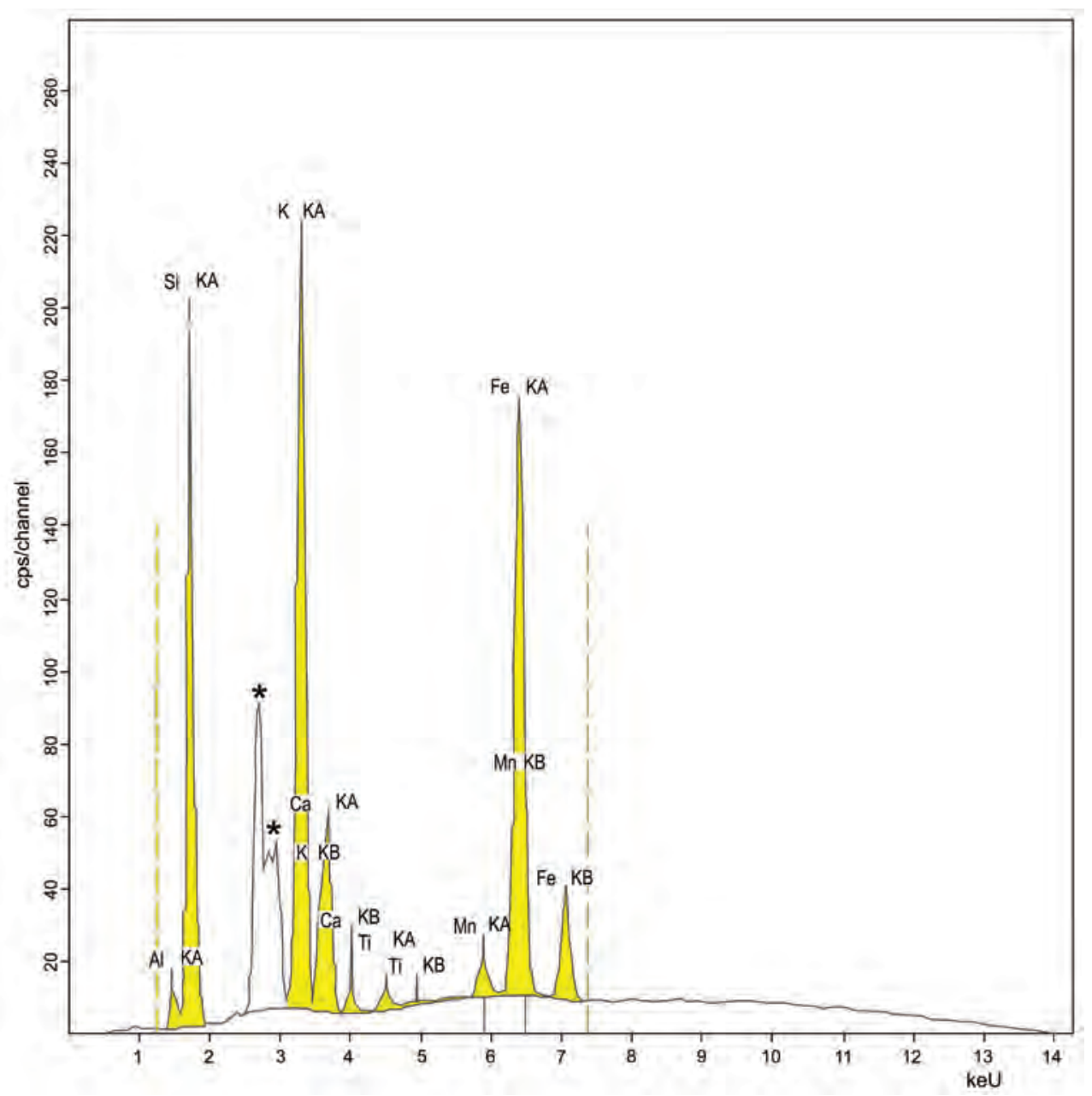

Fig. 9. The XRF spectrum of obsidian from the site 17 in Nowogród, Golub-Dobrzyń district ( ${ }^{*}$ lines derived from cathode and argon excitation). Computer graphics: R. Siuda. 
The results of XRF analysis are presented in Fig. 9 and Table 3. They significantly differ from the PGAA results, which will be more widely discussed below, in the part devoted to the discussion of the research results.

\section{DISCUSSION}

Industries of non-flint rocks in the Late Palaeolithic and Mesolithic of Poland are relatively poorly documented, particularly in the lowland part of the country. Generally, only a few sites have these types of artefacts in the inventories. Quartzite artefacts are known from Polish Magdalenian sites, e.g., Dzierżysław, site 35, Głubczyce district, Wilczyce, site Io, Sandomierz district, Klementowice, site 20, Puławy district (southeastern Poland), and have been found sporadically at Świderian sites, e.g., Czerniewice, Włocławek district. Several artefacts made of quartz have been recorded at the Hamburgian site of Myszęcin (Świebodzin district, western Poland; Kabaciński and Sobkowiak-Tabaka 2013: 156), while a very interesting collection of 56 pieces made of fine-crystalline quartzite was discovered during the study of the multicultural site of Lubrza Io, Świebodzin district (Kabaciński and Sobkowiak-Tabaka 20IIa, 20II b; Osipowicz and Sobkowiak-Tabaka 20I4).

A similar situation can be observed during the Mesolithic. The possibility of treatment of different varieties of non-flint rocks at Polish early Holocene sites was first put forward by Stefan Krukowski and Antoni Nowakowski (Nowakowski 1976: 68). Hanna Więckowska and Maria Chmielewska have also written about early Holocene artefacts of this type (2007: 30-33).

A relatively large, lowland, collection of Mesolithic stone artefacts, from non-flint raw materials, also comes from site 6 at Ludowice and the nearby Mesolithic cemetery at Mszano, Brodnica district (Osipowicz and Sobkowiak-Tabaka 20I4; Osipowicz 20I5). A contrast to the typical assemblages from the Polish lowland are those dominated by Sudeten rocks. The Ścinawa Mesolithic settlement microregion in the Lower Silesian region was perhaps of greatest interest because rocks ideal for Mesolithic knapping, such as jasper, opal, chalcedony, rock crystal, amethyst, agate, lidite, quartzite and trachybasalt, were found in the area (Bronowicki 2008). Pedunculated Komornica truncations are mentioned, for example, at the Ratno Dolne 2 site, Kłodzko district, along with points with horizontally retouched bases made of exotic raw materials like rock crystal, quartzite, porcellanite and Permian chert (Bronowicki and Bobak 1999: 6I; Bronowicki 2002).

Based on previous research on the structure (assortment and frequency) of the Fennoscandian erratics found in the Polish Lowlands, we know that the main source of raw materials for stone processing in prehistory was local post-glacial rock resources, i.e., Fennoscandian erratic boulders and pebbles occurring in sediments that build 
numerous forms of the young glacial landscape in the Polish Lowland (among others Chachlikowski 1994, 1997, 2000, 2007, 2013, 2017, 2018; Chachlikowski and Skoczylas 200Ia, 200Ib). From the current petrographic survey of the structure of rock materials from site 17 at Nowogród, it can be concluded that among the communities settling this site at the end of the Late Palaeolithic, it was also common to use local erratic resources. The exclusive use of locally-available raw materials is demonstrated by the fact that the rock types most commonly used for knapping, quartzite and quartzite sandstone, occur most abundantly among the post-glacial stone materials deposited in Poland (Chachlikowski 1997: I4I-I49, 20I3: I9-24, 60-I28, 20I8). The probability of imports within this group of non-flint raw materials is therefore very small. This goes against current perceptions of the structure of the imported raw materials used on the Polish Lowland in prehistory (Chachlikowski 1996, 1997: 37-44, I72-181, 2013, 20I8; Chachlikowski and Skoczylas 20orb, and references therein).

Thus, for their stone industry, the Late Palaeolithic communities living in the area of Nowogród I7 probably benefited from the natural resources within the near vicinity of the site. It should be assumed that boulders and pebbles of the material exploited are found in the form of natural accumulations of rock blocks, residual morainic material embedded by the Fennoscandian ice sheet in the early post-glacial landscape of the lowland. It is known that these local accumulations of lithic materials were extremely abundant, and at the same time varied in lithological composition; these reservoirs of raw materials were useful in prehistoric stone processing, and were also used as building materials. These raw materials were probably obtained through gathering (from the ground surface), and also exploited using the open-pit method to extract appropriate (in terms of lithology and size) stone raw materials from the surrounding Pleistocene deposits (Chachlikowski 1994, 1997: I49-I7I, 2008, 2013: 40-59, 97-IO6, 2017). The Grodno-Plebanka tunnel valley, in which site i7 at Nowogród occurs, was ideally situated in this respect. Both its slopes and part of the post-glacial thresholds present here consist of sands and gravels deposited during the main stadial of the Weichselian Glaciation (Wysota 2006, 2007). The highest of the thresholds is located in the vicinity of site I7 at Nowogród. Within its area, on the surface of the Grodno-Plebanka tunnel valley, clusters of erratic boulders were found. Coarse-grained sediments (boulders and gravels), which are commonly found within in the Grodno-Plebanka tunnel valley, are directly related to the genesis of this landform. It was created as a result of the erosion of snowmelt waters beneath the Scandinavian ice sheet during the Weichselian Glaciation. The existence of boulder clusters and coarse gravels may therefore be the result of the fine fraction washout from glaciogenic sediments by melt waters under the ice sheet. These waters, flowing under high hydrostatic pressure, eroded the ice sheet substrate, causing the formation of the Grodno-Plebanka tunnel valley, while the deposits of boulder-gravel material commonly found in the bottom of the tunnel valley and in the vicinity of archaeological sites are coarse-grained residua of glaciogenic deposits. 
I20 $\mid$ Osipowicz et al

Obsidian artefacts attributed to the Middle Palaeolithic are known from three sites: Rybnik: site A, Rybnik district, Obłazowa Cave, Nowy Targ district, and Ciemna Cave, Cracow district (Ginter 1986; Valde-Nowak et al., 2003). In the Upper Palaeolithic, the utilization of obsidian increased. Single finds occur in assemblages attributed to the Szeletian (Obłazowa Cave, layer XI; Valde-Nowak et al., 2003), Aurignacian (Kraków-Zwierzyniec; Cracow district; Sawicki 1949) and Gravettian (Kraków-Spadzista Street; Sobczyk 1995). A good example is the Epigravettian site of Targowisko io near Cracow (Wilczyński 20Io). The site also yielded the largest collection of obsidian artefacts from Palaeolithic Poland. Magdalenian obsidian is known from the Ćmielów 'Mały Gawroniec' site Ostrowiec Świętokrzyski district (Sulgostowska 2005: 49; Przeździecki et al., 20I2). Numerous obsidian finds are connected with Arched Backed Piece Technocomplex concentrations of the Rydno complex, Starachowice district (Schild and Królik 1981; Tomaszewski et al., 2008). Other sites where obsidian is present are located in southern Poland, namely Nowa Biała I, Nowy Targ district, Sromowce-Niżne I, Nowy Targ district (Valde-Nowak 1987), Skwirtne I, Gorlice district (Valde-Nowak 199I) and Tylicz A, Nowy Sącz district (Tunia 1978). Obsidian was also used by societies connected with the Tanged Point Technocomplex. There are only two sites on the Plain where Late Palaeolithic obsidian artefacts have been found, Koło district, and Mokrsko, Wieluń district (Sobkowiak-Tabaka et al., 20I5). From southern Poland, a few stray finds are also known - 'somewhere near Płock', Kraków-Bagno, Cracow district, Glanów, Olkusz district, Czerniejów Site 2, Lublin district, Kraków-Bieżanów Site I5, Cracow district and Wołodź, Brzozów district (Krukowski 1920; Osipowicz and Szeliga 2004; Sulgostowska 2005). Single obsidian artefacts may also be attributed to the Swiderian settlement complex at Rydno (Schild et al., 20II).

Against this background, the obsidian artefact from Nowogród, which is probably connected with the Swiderian culture, should be considered as an important find. Its presence at a site located so far north makes it important to carry out analyses aimed at determining the geological source of the raw material used. The PGAA study, which indicates an origin in the Carpathian I source area in Slovakia, can be compared with the results of this type of analysis carried out on other obsidian artefacts with identical or similar chronology. PGAA was also performed on obsidian from two Late Palaeolithic sites on the Polish Plain: Cichmiana and Mokrsko (Jażdżewski 1929; Kabaciński and Sobkowiak-Tabaka 2009). The results of the analyses showed that they are also most similar to the Carpathian I source (i.e., Slovakian, northern part of the Tokaj Mountains; Sobkowiak-Tabaka et al., 20I5). Non-destructive energy dispersive X-ray fluorescence (EDXRF) analysis was performed on obsidian artefacts from Mesolithic layers at the Rydno XIII/I959 site in central Poland (Hughes and Werra 20I4). Element concentration values for the obsidian artefacts from this site indicate that the tools analysed were manufactured from Carpathian Ia/Ib obsidian. Important data was 
provided by the latest research by Richard E. Hughes, Dagmara H. Werra and Zofia Sulgostowska (2018) that examined 86 obsidian artefacts from twenty Palaeolithic and Mesolithic archaeological sites in Poland. The artefacts were analysed with the use of non-destructive EDXRF (Hughes et al., 20I8: Table 5, 85), which showed that all Late and Final Palaeolithic, and also Mesolithic communities, used obsidian from the same outcrops - those of the Carpathian I chemical type in Slovakia.

The results of the XRF analysis of the obsidian artefact from the Nowogród site are significantly different from the results obtained by the PGAA method. As stated above, using PGAA we were able to quantify most of the major components, as well as some trace elements. With XRF, a more limited range of elements was measured (as oxide values: $\mathrm{Al}_{2} \mathrm{O}_{3}, \mathrm{SiO}_{2}, \mathrm{~K}_{2} \mathrm{O}, \mathrm{CaO}, \mathrm{TiO}_{2}, \mathrm{MnO}, \mathrm{Fe}_{2} \mathrm{O}_{3}$ ). It has been shown that $\mathrm{B}, \mathrm{Cl}$ and $\mathrm{TiO}_{2}$ provide an important 'fingerprint' for obsidian. According to the $\mathrm{TiO}_{2}$ content, not only can the major groups of obsidian sources be distinguished: Carpathian I: outcrops in the vicinity of Viničky and Cejkov (Slovakia), Carpathian 2: Tokaj Mts. in Hungary, Carpathian 3: in the vicinity of Rokosovo (Ukraine), Lipari, Melos and Sardinia; but subtypes, especially those from Melos (subtype Demenegaki and Adama) and Sardinia (subtype A, B and C), can also be identified (compare Sobkowiak-Tabaka et al., 2015; Kasztovszky et al., 2018). The XRF analysis provided data on only one of the chemical compounds listed above, i.e., $\mathrm{TiO}_{2}$. Unfortunately, the results obtained here are not even close to those obtained with PGAA method. They also do not fit in the average values specified for any obsidian outcrops, because the maximum value for $\mathrm{TiO}_{2}$ is 0.20 Conc./wt\% (Kasztovszky et al., 2018: 184, Fig. 3b). The concentrations of other elements also differs between the PGAA and XRF analyses. Such large discrepancies can result from many factors. They may result from the sample preparation procedure and the way the analyses were conducted. To obtain reliable results for non-metallic materials using XRF, the sample should ideally be crushed, ground and then melted with a suitable flux. After melting, a suitable pellet is heat-formed from the enamel obtained, which is then analysed. In the case of archaeological artefacts this is out of the question, so the entire object is inserted into the apparatus and exposed to X-rays. Unfortunately, this type of analysis is flawed. The results may also vary according to the size of the analysed object, unevenness of the surface subjected to radiation, and other factors. Moreover, comparative studies of obsidian by PGAA and XRF have shown no correlation for elements such as $\mathrm{Al}$ and $\mathrm{Si}$, and weak correlation for $\mathrm{Ti}$ and $\mathrm{K}$. Similar results were obtained for elements such as $\mathrm{Ca}, \mathrm{Mn}$ and Fe. The poor agreements between the PGAA and XRF data, especially for $\mathrm{Al}_{2} \mathrm{O}_{3}$ and $\mathrm{SiO}_{2}$, can be explained partly by the absorption of the low energy characteristic X-rays in the air between the sample and the detector. Also, it should be emphasized that PGAA provides compositional data as an average over the whole irradiated volume, while XRF shows the composition of the outer few-tens-of-microns of the sample (Kasztovszky et al., 20I8). 
I22 $\mid$ Osipowicz et al

Finally, it is worth discussing the possibility of linking the rock crystal found at Ludowice with the Mesolithic settlement. Besides the above noted Ratno Dolne 2 site, Kłodzko district, rock crystal was also present in the inventories of other Mesolithic sites in southern Poland, such as Jegłowa Site 2, Strzelin district (Bobak 1996, 1997) and Bielawa Site I2, Dziorżonów district (Bronowicki 1999). Importantly, the objects from Jegłowa Site 2 constitute the richest collection of rock-crystal artefacts from that area of Poland and comprises tools, raw products and waste, which indicates knowledge of the technological properties and use of this raw material by early Holocene communities in the area of what is today Poland. A connection between the pieces of rock crystal found at Ludowice and the Mesolithic communities is therefore perfectly possible, although it cannot be confirmed at the present stage of research.

\section{CONCLUSIONS}

The research on the small collection of non-flint stone artefacts discovered on site I7 at Nowogród has undoubtedly provided some interesting information, among which the most important is that associated with the obsidian artefact and the pebble tool. The presence of the latter is important evidence for the knapping of coarsely crystalline stone raw materials in order to create more than just grinding plates and grinders, as previously was thought to be the case. However, the results of the analyses carried out may also be the basis for asking many questions, especially those of a general nature, most importantly what was the real significance of this type of raw material for Late Palaeolithic communities. In an era of access to good quality flint resources, was their processing and use dictated by economic factors, or related to cultural or ritual factors, or even a matter of chance or mere curiosity? The answer to these questions undoubtedly requires the analysis of a much larger number of finds of this type. One thing is certain - this type of material must not be overlooked or underestimated.

\section{ACKNOWLEDGMENTS}

The site discussed here was excavated as part of the scientific project financed by the National Science Centre (NCN) in Cracow (Poland) no. 2016/23/B/HS3/oo689.

\section{REFERENCES}

Bobak, D. 1996. Ślady osadnictwa z epoki kamienia w Jegłowej, gm. Przeworno. Ślaskie Sprawozdania Archeologiczne 37: 319-323. 
Bobak, D. 1997. Badania mezolitycznego stanowiska Jegłowa 2, gm. Przeworno. Ślaskie Sprawozdania Archeologiczne 39: 395-399.

Bronowicki, J. 1999. Mezolityczny mikroregion osadniczy w okolicach Bielawy u podnóża Gór Sowich. Studia Archeologiczne 3I: 79-II6.

Bronowicki, J. 2002. Obozowisko mezolityczne Ratno Dolne 2, pow. Kłodzko. Acta Archaeologica Carpathica 37: 5-18.

Bronowicki, J. 2008. Kamieniec, pow. kłodzki. Ścinawski mikroregion osadnictwa mezolitycznego. Silesia Antiqua 44: 254-257.

Bronowicki, J. and Bobak, D. 1999. Problem mezolitu w Sudetach. In P. Valde-Nowak (ed.), Początki osadnictwa w Sudetach, 53-74. Kraków.

Chachlikowski, P. 1994. Późnoneolityczne wybierzysko surowców skał niekrzemiennych w miejscowości Goszczewo, gm. Aleksandrów Kujawski, woj. Włocławek, stanowisko i3. Folia Praehistorica Posnaniensia 6: 59-I2I.

Chachlikowski, P. 1996. Ze studiów nad pochodzeniem i użytkowaniem surowców importowanych w wytwórczości kamieniarskiej społeczności wczesnorolniczych Kujaw. In A. Kośko (ed.), Z badań nad geneza regionalizmu kulturowego spoteczeństw Kujaw, I2I-I53. Poznań-Inowrocław.

Chachlikowski, P. 1997. Kamieniarstwo późnoneolitycznych spoteczeństw Kujaw. Poznań.

Chachlikowski, P. 2000. Kamieniarstwo społeczności kultur późnoneolitycznych. In A. Kośko (ed.), Archeologiczne badania ratownicze wzdtuż trasy gazociagu tranzytowego, Tom III, Kujawy, cz. 4. Osadnictwo kultur póżnoneolitycznych oraz interstadium epok neolitu i brąu: 3900-I400/I300 przed Chr., 393-409 and 605-606. Poznań.

Chachlikowski, P. 2007. Przetwórstwo i użytkowanie surowców kamiennych. In A. Kośko and M. Szmyt (eds), Opatowice - Wzgórze Prokopiaka. Tom III. Studia i materiaty do badań nad późnym neolitem Wysoczyzny Kujawskiej, 315-338. Poznań.

Chachlikowski, P. 2008. Osadnictwo wielokulturowe na stanowisku 8 w Chtopinach, gm. Lubiszyn, woj. lubuskie, typescript, Institute of Archaeology, Adam Mickiewicz University, Poznań.

Chachlikowski, P. 2013. Surowce eratyczne w kamieniarstwie spoteczeństw wczesnoagrarnych Niżu Polskiego (IV-III tys. przed Chr.). Poznań.

Chachlikowski, P. 20I7. Mining of lithic erratic raw material in the Polish Lowland in prehistory - a precedent or common practice? In A. Marciniak-Kajzer, A. Andrzejewski, A. Golański, S. Rzepecki and M. Wąs (eds), Nie tylko krzemienie. Not only flints, 369-387. Łódź.

Chachlikowski, P. 20I8. The erratic stone raw material reservoir in the Polish Lowland and its procurement and selection within the local late Neolithic societies. Choices between the "gift" from the glacial past and the Earth's natural resources of the "south". In P. Valde-Nowak, K. Sobczyk, M. Nowak and J. Źrałka (eds), Multas per gentes et multa per saecula. Amici magistro et collegae suo - Ioanni Christopho Koztowski dedicant, 537-546. Kraków.

Chachlikowski, P. and Skoczylas, J. 20ora. Exploration of stone raw-materials in stone industry of lateneolithic communities of Lowland Poland (Niż Polski). Prospects for further petroarchaelogical studies in the Kujawy region. Przeglad Archeologiczny 49: 17-34.

Chachlikowski, P. and Skoczylas, J. 20orb. Pochodzenie i użytkowanie surowców kamiennych spoza Niżu Polskiego w neolicie i wczesnej epoce brązu na Kujawach. Fontes Archaeologici Posnanienses 39: 163-190.

Ginter, B. 1986. Obsidianimporte im Spätpaläolithikum und Mesolithikum in Südpolen. In Urzeitliche Und Frühhistorisches Besiedlung der Ostslowakei in Bezug zu den Nachbarngebieten, 7I-76. Nitra.

Hughes, R.E. and Werra, D.H. 20I4. The source of Late Mesolithic obsidian recovered from Rydno XIII/I959, Central Poland. Archeologia Polski 59: 31-46. 
$\mathrm{I24} \mid$ Osipowicz et al

Hughes, R.E., Werra, D.H. and Sulgostowska Z. 20I8. On the sources and uses of obsidian during the Paleolithic and Mesolithic in Poland. Quaternary International 468: 84-Ioo, https://doi. org/IO.IOI6/j.quaint.20I7.II.0I3.

Jażdżewski, K. 1929. Osadnictwo prehistoryczne nad górną Prosną. Z Otchtani Wieków 4 (5-6): 85-94.

Kabaciński, J. and Sobkowiak-Tabaka I. 2009. Big game versus small game hunting - subsistence strategies of the Hamburgian culture. In M. Street, N. Barton and T. Terberger (eds), Humans, environment and chronology of the Late Glacial of the North European Plain, 67-75. Mainz.

Kabaciński, J. and Sobkowiak-Tabaka, I. 2orıa. Schyłkowy paleolit i mezolit. In J. Kabaciński and I. Sobkowiak-Tabaka (eds), Osadnictwo pradziejowe i wczesnośredniowieczne w Lubrzy. Ratownicze badania archeologiczne Instytutu Archeologii i Etnologii PAN, Oddziat w Poznaniu, T. III, 2I-28. Poznań, Institute of Archaeology and Ethnology, Polish Academy of Sciences.

Kabaciński, J. and Sobkowiak-Tabaka, I. 2orıb. Schyłkowy paleolit. In J. Kabaciński and I. SobkowiakTabaka (eds), Materiaty do wczesnych pradziejów Zachodniej Wielkopolski. Osadnictwo pradziejowe i wczesnośredniowieczne w Lubrzy. Ratownicze badania archeologiczne Instytutu Archeologii i Etnologii PAN, Oddziat w Poznaniu, T. III, 195-262. Poznań, Institute of Archaeology and Ethnology, Polish Academy of Sciences.

Kabaciński, J. and Sobkowiak-Tabaka, I. 2013. Osadnictwo spoteczności kultury hamburskiej na Pojezierzu Lubuskim. Ratownicze Badania Archeologiczne Instytutu Archeologii i Etnologii PAN Ośrodek Studiów Pradziejowych i Średniowiecznych, T. V. Poznań, Institute of Archaeology and Ethnology, Polish Academy of Sciences.

Kasztovszky, Zs., Biró, K.T., Markó, A. and Dobosi, V. 2008. Cold neutron prompt gamma activation analysis e a non-destructive method for characterization of high silica content chipped stone tools and raw materials. Archaeometry 50 (I): I2-I9.

Kasztovszky, Zs., Maróti,, B., Harsányi I., Párkányi, D. and Szilágyi, V. 2018. A comparative study of PGAA and portable XRF used for non-destructive provenancing archaeological obsidian. Quaternary International 468: 179-I89.

Krukowski, S. 1920. Pierwociny krzemieniarskie górnictwa, transportu i handlu w holocenie Polski. Wnioski z właściwości surowców i wyrobów. Wiadomości Archeologiczne 5: 185-206.

Nowakowski, A. 1976. Surowce wulkaniczne Wieliszewa. In S.W. Krukowski and A. Nowakowski (eds), SKAM 7I, Zbiór rozpraw prahistorycznych, 67-75. Warszawa, Zakład Narodowy im. Ossolińskich.

Osipowicz, G. 2010. Narzędzia krzemienne w epoce kamienia na ziemi chetmińskiej. Toruń.

Osipowicz, G. 20I5. Zorganizowane i wyspecjalizowane obozowisko zbieraczy? Z wyników badań traseologicznych i przestrzennych materiałów mezolitycznych ze stanowiska Ludowice 6. Przeglad Archeologiczny 63: 59-85.

Osipowicz, G. 20I7a. Ludowice 6 site, western habitation: A silica plant processing female gatherer campsite?. Journal of Archaeological Science: Reports, http://dx.doi.org/I0.IoI6/j.jasrep.2017.08.019

Osipowicz, G. 20I7b. Spoteczności mezolityczne Pojezierza Chetmińsko-Dobrzyńskiego : próba modelowej analizy wieloaspektowej funkcji i organizacji przestrzennej wybranych obozowisk. Toruń, Wydawnictwo Naukowe Uniwersytetu Mikołaja Kopernika.

Osipowicz, G., Jankowski, M., Makowiecki, D. and Weckwerth, P. 2oI4. Obozowiska mezolityczne ze stanowiska Ludowice 6, woj. kujawsko-pomorskie, siedlisko zachodnie. Wiadomości Archeologiczne 65: I49-195.

Osipowicz, G. and Sobkowiak-Tabaka, I. 20I4. New evidences for core processing of non-flint, lithic materials in the Late Palaeolithic and Mesolithic of Poland. Journal of Lithic Studies I(I): I-I4

Osipowicz, G. and Szeliga M. 2004. Analiza funkcjonalna obsydianowego liściaka schyłkowopaleolitycznego ze st. 7 w Wołodzi, woj. podkarpackie. Acta Archaeologica Carpathica 39: 153-160. 
Przeździecki, M., Migal, W., Krajcarz, M. and Pyżewicz, K. 20I2. Obozowisko kultury magdaleńskiej na stanowisku 95 "Mały Gawroniec" w Ćmielowie, pow. ostrowiecki, woj. świętokrzyskie (Pl. I04eII5). Światowit 8, 48. Fascykuł B: 225-234.

Révay, Zs. 2009. Determining elemental Composition Using Prompt Gamma Activation Analysis. Analytical Chemistry 8I: 685I.

Révay, Zs., Firestone, R.B., Belgya, T., and Molnár, G.L. 2004. Catalog and Atlas of Prompt Gamma Rays. In G.L. Molnár (ed.), Handbook of Prompt Gamma Activation Analysis with Neutron Beams, 173-364. Dordrecht-Boston-New York, Kluwer Academic Publishers.

Sawicki, L. 1949. Wyniki badań obozowiska myśliwców z epoki lodowcowej na Zwierzyńcu w Krakowie. Archeologické Rozhledy i: 74-76.

Schild R. and Królik, H. 1981. Rydno a Final Palaeolithic Ochre Mining Complex. Przeglad Archeologiczny 29: 53-100.

Schild, R., Królik, H., Tomaszewski, A.J. and Ciepielewska, E. 2oIr. Rydno. A Stone Age Red Ochre Quarry and Socioeconomic Center. A Century of Research. Warszawa.

Sobczyk, K. 1995. Osadnictwo wschodniograweckie w dolinie Wisty pod Krakowem. Kraków.

Sobkowiak-Tabaka, I., Kasztovszky, Zs., Kabaciński, J., T. Biró, K., Maróti, B. and Gméling, K. 2015. Transcarpathian contacts of the Late Glacial Societies of the Polish Lowlands. Przeglad Archeologiczny 63: 5-28.

Sulgostowska, Z., 2005. Kontakty spoteczności późnopaleolitycznych i mezolitycznych między Odrą a Dźwina i górnym Dniestrem. Warsaw, Institute of Archaeology and Ethnology, Polish Academy of Sciences.

Szentmiklósi, L., Belgya, T., Revay, Zs. and Kis, Z. 20Io. Upgrade of the prompt gamma activation analysis and the neutron-induced prompt gamma spectroscopy facilities at the Budapest research reactor. The Journal of Radioanalytical and Nuclear Chemistry 286: 50I-505.

Tomaszewski, A.J., Królik, H., Ciepielewska, E., Laprus-Madej, B. and Mańka, D. 2008. Rydno’s obsidians: almost all of them. In: Z. Sulgostowska and A.J. Tomaszewski (eds), Man-MilleniumEnvironment: Studies in Honor of Romuald Schild, 293-300. Warsaw, Institute of Archaeology and Ethnology, Polish Academy of Sciences.

Tunia, K. 1978. Sprawozdanie z badań stanowiska z epoki kamienia w Tyliczu, woj. Nowy Sącz. Acta Archaeologica Carpathica I8: 227-233.

Więckowska, H. and Chmielewska, M. 2007. Materiaty do badań osadnictwa mezolitycznego w mikroregionie Luta, województwo lubelskie. Warsaw, Institute of Archaeology and Ethnology, Polish Academy of Sciences.

Wilczyński, J. 20Io. Obsidian products from Targowisko site ıo (powiat district of Wieliczka). In J. Gancarski (ed.), Transkarpackie kontakty kulturowe w epoce kamienia, brązu i wczesnej epoce żelaza, II5-I37. Krosno.

Wysota, W. 2006. Szczegótowa mapa geologiczna Polski w skali I:50ooo, arkusz Golub Dobrzyń. Warszawa, Państwowy Instytut Geologiczny.

Wysota, W. 2007. Objaśnienia do Szczegótowej mapy geologicznej Polski w skali I:50ooo, arkusz GolubDobrzyń, I-5I. Warszawa, Państwowy Instytut Geologiczny.

Valde-Nowak, P. 1987. Entdeckung der Paläolithischen Fundstellen im Tal des Białka Tatrzańska-Flusses. Acta Archaeologica Carpathica 26: 5-35.

Valde-Nowak, P. 199I. Studies in Pleistocene Settlement in The Polish Carpathians. Antiquity 65: 593-606.

Valde-Nowak, P., Nadachowski, A. and Madeyska, T. (eds) 2003. Obłazowa Cave: Human Activity, Stratigraphy and Palaeoenvironment. Kraków. 
